\title{
Severe asthma in adolescence - or how the low self-esteem obstacles the therapy
}

\author{
Guergana Petrova, Sylvia Shopova, Dimitrinka Miteva, Snezhina Lazova*, Penka Perenovska \\ From 2nd International Severe Asthma Forum (ISAF) \\ Athens, Greece. 13-15 November 2014
}

\section{Background}

Adolescent with any chronic disease face rebellious stage of puberty aggravated with the condition they have usually requiring strict food and behavioral regimen. Sometimes during this period a seemingly "well-controlled" asthma turns out to be "uncontrolled" despite the increase in therapy and thus classifying it as a severe asthma as defined as ERS/ATS guidelines.

\section{Clinical case}

We present a case of 17-year old girl with bronchial asthma, hospitalized in the clinic multiple times, despite high dose of combined corticosteroids as a controller medication. The child starts to show protest behavior towards therapy, that's modifying in the course of psychological maturation - denial of the medicines, unhealthy and hazardous life styles. At the age of 16-years depression was diagnosed, and was pharmacological and psychological therapy. This case is presented with aim to show specific for most of the asthmatic patients' negative selfestimation for their quality of life and how it requires complex theurapetical approach.

\section{Conclusion}

A modern team-work approach with respiratory/allergy specialist and psychology/psychiatry specialist sometimes is the best way to manage teenagers with difficult to treat asthma.

\section{Consent}

Written informed consent was obtained from the patient for publication of this abstract and any accompanying images. A copy of the written consent is available for review by the Editor of this journal.

UH "Alexandrovska", Pediatric clinic, Sofia, Bulgaria
Published: 23 March 2015

doi:10.1186/2045-7022-5-S2-P20

Cite this article as: Petrova et al:: Severe asthma in adolescence - or how the low self-esteem obstacles the therapy. Clinical and Translational Allergy 2015 5(Suppl 2):P20.
Submit your next manuscript to BioMed Central and take full advantage of:

- Convenient online submission

- Thorough peer review

- No space constraints or color figure charges

- Immediate publication on acceptance

- Inclusion in PubMed, CAS, Scopus and Google Scholar

- Research which is freely available for redistribution 